\title{
PENERAPAN AJUDIKASI KHUSUS OLEH OMBUDSMAN REPUBLIK INDONESIA TERHADAP PENYELENGGARA NEGARA YANG MALADMINISTRASI
}

\author{
Andi Anas Chaerul M. \\ Universitas Muslim Indonesia Makassar \\ Email: andianaschaerul@gmail.com
}

\begin{abstract}
The Ombudsman carries out the function of settling public service disputes in terms of settling compensation, one of which is through special adjudication as stipulated in RI Law Number 25 of 2009 concerning Public Services. However, the fact is that until now the Special Adjudication mechanism has never been implemented. The application of Special Adjudication by the Ombudsman of the Republic of Indonesia to state administrators who were maladministrated was ineffective. Factors affecting the ineffectiveness of the application of the Special Adjudication by the Ombudsman to state administrators who are maladministrated are legal factors in the absence of implementing regulations (Presidential Regulation) governing the mechanisms and provisions for compensation payments, factors for charging compensation, and human resource factors and facilities infrastructure

Keywords: Ombudsman, Special Adjudication
\end{abstract}

\begin{abstract}
Abstrak
Ombudsman melaksanakan fungsi penyelesaian sengketa pelayanan publik dalam hal penyelesaian ganti rugi yang salah satunya melalui jalan ajudikasi khusus sebagaimana diatur dalam Undang-Undang RI Nomor 25 Tahun 2009 Tentang Pelayanan Publik. Namun, faktanya hingga saat ini mekanisme Ajudikasi Khusus belum pernah dilaksanakan. Penerapan Ajudikasi Khusus oleh Ombudsman Republik Indonesia terhadap penyelenggara negara yang maladministrasi tidak efektif. Faktor-faktor yang mempengaruhi tidak efektifnya penerapan Ajudikasi Khusus oleh Ombudsman terhadap penyelenggara negara yang maladministrasi adalah faktor hukum dengan tidak adanya aturan pelaksana (Peraturan Presiden) yang mengatur mekanisme dan ketentuan pembayaran ganti rugi, faktor pembebanan ganti kerugian, dan faktor sumber daya manusia dan sarana prasarana
\end{abstract}

Kata Kunci : Ombudsman, Ajudikasi Khusus 


\section{PENDAHULUAN}

erakan reformasi mengamanatkan perubahan kehidupan bernegara, Tberbangsa, dan bermasyarakat yang lebih baik, yaitu kehidupan bernegara yang didasarkan pada pemerintahan yang demokratis dan berlandaskan hukum dalam rangka meningkatkan kesejahteraan serta menciptakan keadilan bagi seluruh warga negara. Sebagaimana diketahui penyelenggaraan tugas kewajiban negara yang dibebankan kepada penyelenggara pemerintahan antara lain memberikan pelayanan kepada masyarakat dimana tugas tersebut secara umum tidak hanya menjadi ruang lingkup tugas dan kewajiban aparatur pemerintah tetapi meliputi pula aparatur lembaga peradilan dan lembaga-lembaga negara lainnya yang dalam pelaksanaan tugasnya berkaitan dengan pelayanan kepada masyarakat.

Era sebelum reformasi, kehidupan masyarakat dan ekonomi nasional cenderung diwarnai praktek-praktek korupsi, kolusi, dan nepotisme (KKN), sehingga mutlak diperlukan pemerintahan yang baik dan bersih (good governance) melalui upaya penegakan asas-asas pemerintahan yang baik pada khususnya dan penegakkan hukum pada umumnya. Dalam rangka menegakkan pemerintahan yang baik dan upaya meningkatkan pelayanan kepada masyarakat diperlukan keberadaan lembaga pengawas yang secara efektif mampu mengontrol penyelenggaraan tugas aparat penyelenggara negara. Pengawasan secara internal yang dilakukan oleh pemerintah sendiri dalam tataran implementasi kurang memenuhi harapan masyarakat dari sisi obyektivitas dan akuntabilitas.

Salah satu masalah krusial yang dihadapi bangsa Indonesia saat ini adalah menguatnya gejala public distrust di tengah-tengah masyarakat, sebagai akibat kesalahan berbagai instrumen birokrasi rezim masa lalu. Setidaknya ada beberapa indikator yang dapat dijadikan ukuran menguatnya gejala public distrust di tengah-tengah masyarakat. Paling menonjol antara lain adalah mulai membudayanya perilaku main hakim sendiri di tengah-tengah masyarakat dalam menyikapi tindak kejahatan di lingkungan sekitarnya, perusakan fasilitas umum sebagai representasi kekecewaan masyarakat terhadap simbol-simbol kekuasaan, aksi menentang kebijakan pemerintah yang dilakukan secara massive, dan banyak lagi.

Dalam konteks penegakan hukum, fenomena maraknya perilaku main hakim sendiri (eigenrichting) yang dilakukan oleh masyarakat terhadap pelaku-pelaku kejahatan dapat membuka peluang bagi terjadinya social disorder. Ini merupakan salah satu indikasi bahwa pada level tertentu, masyarakat sudah tidak mempercayai institusi penegak hukum yang berlaku resmi. Hal tersebut tidak dapat dianggap remeh, sebab biasanya merupakan refleksi yang secara simbolik 
diisyaratkan masyarakat untuk membahasakan persoalan-persoalan penegakan hukum yang lebih besar. ${ }^{1}$

Memperhatikan fakta di atas kiranya dapat dikemukakan bahwa ternyata masih terdapat celah-celah yang secara mendasar tidak atau belum merupakan sasaran pengawasan. Dari aspek kelembagaan juga belum ada lembaga yang secara optimal memperoleh pengakuan dan diterima sebagai pengawas. Bahkan juga belum ada prosedur yang dapat menjembatani antara mekanisme yang bersifat kaku sebagai akibat sistem struktural hierarkis di satu pihak dengan mekanisme lentur/pendek dari suatu organisasi yang tidak struktural hierarkis. Dengan demikian diperlukan suatu jalan keluar yang diharapkan pada satu sisi merupakan jalan tengah bagi kepentingan pengemban sistem struktural hierarkis serta kepentingan pengemban sistem non struktural, namun pada sisi lain mampu menampung seluruh aspirasi warga masyarakat tanpa harus melewati sistem prosedur atau mekanisme yang berliku-liku.

Pengawasan secara internal yang dilakukan oleh pemerintah sendiri dalam tataran implementasi kurang memenuhi harapan masyarakat dari sisi obyektifitas dan akuntabilitas. Oleh karena itu, berdasarkan Keputusan Presiden Nomor 44 Tahun 2000 tentang Komisi Ombudsman Nasional dibentuk Komisi Ombudsman Nasional yang antara lain bertujuan melalui peran serta masyarakat membantu menciptakan dan mengembangkan kondisi yang kondusif dalam melaksanakan pemberantasan Korupsi, Kolusi, dan Nepotisme (KKN) serta meningkatkan perlindungan hak-hak masyarakat agar memperoleh pelayanan umum, keadilan, dan kesejahteraan secara adil.

Dilandasi oleh kondisi baik yang mencakup substansi pengawasan, prosedur maupun kelembagaan maka Ombudsman merupakan salah satu alternatif. Tentu di dunia ini tidak ada satu lembaga pun yang merupakan obat ajaib dalam arti menyembuhkan segala macam penyakit dengan seketika. Tetapi setidaknya sekarang ini sudah kurang lebih 130 negara memiliki Ombudsman (dengan sebutan bermacam-macam) baik Ombudsman Nasional maupun Ombudsman Daerah dan lebih dari 50 negara telah mencantumkannya dalam konstitusi. Apabila banyak negara telah memiliki Ombudsman tentunya mereka merasakan perlunya institusi ini dalam penyelenggaraan negara demi kesejahteraan masyarakat.

\footnotetext{
1 Antonius Sujata dan Surahman, 2002, Ombudsman Indonesia di tengah Ombudsman Internasional, Komisi Ombudsman Nasional:Jakarta.
} 
Dari sisi aparatur penyelenggara negara/aparat pemerintah termasuk lembaga peradilan saat ini masih pada tahap memperoleh pengakuan awal bahwa setidaknya ada lembaga yang senantiasa dapat memantau mereka. Adanya perasaan tersebut tentu pada akhirnya memberi dampak sikap kehati-hatian. Dengan sikap semacam itu, sadar atau tidak sadar, sebenarnya institusi terkait telah mulai melakukan koreksi diri serta pembenahan demi perbaikan cara-cara dalam memberi pelayanan. Di sini ternyata bahwa proses pembenahan tersebut dilakukan atau dimulai dengan adanya pengawasan oleh Lembaga Independen Ombudsman.

Sebagaimana diamanatkan dalam Keputusan Presiden Nomor 44 Tahun 2000, keberadaan lembaga Ombudsman sebagai lembaga pengawasan eksternal atas penyelenggaraan negara perlu dituangkan dalam Undang-Undang agar mempunyai tugas, fungsi, dan wewenang yang jelas dan kuat, maka disahkanlah undang-undang Ombudsman pada tahun 2008. Dalam undang-undang ini, Ombudsman mempunyai kewenangan memeriksa hal-hal yang sifatnya maladministrasi, kedudukan Ombudsman adalah sebagai lembaga negara yang independen. Hal ini dimaksudkan agar dalam melaksanakan tugasnya Ombudsman dapat bersikap obyektif, transparan, dan mempunyai akuntabilitas kepada publik. Meski tidak bertanggungjawab kepada DPR namun Ombudsman RI wajib menyampaikan laporan tahunan maupun laporan berkala kepada DPR sebagai bentuk pertanggungjawaban kepada publik atas pelaksanaan tugasnya.

Sebagai lembaga yang mengemban tugas pengawasan, Ombudsman Republik Indonesia sekaligus memiliki kewenangan melakukan pemeriksaan tertentu khususnya terkait dengan dugaan adanya tindakan maladministrasi yang dilakukan oleh penyelenggara Negara, penyelenggara pemerintahan serta lembaga peradilan, baik yang dilaporkan masyarakat ataupun inisiatif sendiri. Dalam hal pengawasan terhadap penyelenggara pelayanan publik, Ombudsman dapat juga melaksanakan fungsi penyelesaian sengketa pelayanan publik dalam hal penyelesaian ganti rugi, melalui jalan mediasi, konsiliasi dan ajudikasi khusus sebagaimana diatur dalam Pasal 50 Ayat (5) Undang-Undang RI Nomor 25 Tahun 2009 Tentang Pelayanan Publik.

Perbuatan maladministrasi yang dilakukan oleh aparat penyelenggara negara tentunya dapat merugikan masyarakat. Seperti contoh kasus dugaan malpraktik yang dilakukan oleh oknum perawat dan dokter yang menyebabkan pasien meninggal dunia di Rumah Sakit I Lagaligo Kec. Wotu Kab. Luwu Timur. ${ }^{2}$ Kasus

2 indonesiasatu.co.id diakses pada 26 Januari 2020 
lain yang terjadi di RS Hikmah Masamba Kab. Luwu Utara yang diduga seorang anak menjadi korban malpraktik di RS tersebut.

Atas hal tersebut, tentunya para korban yang diduga menjadi korban malpraktik mengalami kerugian baik dari segi materiil maupun immaterial. Dalam ajaran islam, ketentuan mengenai pemberian ganti rugi telah dijelaskan dalam $\mathrm{Al}$ Qur'an, sebagaimana dijabarkan dalam fatwa Dewan Syariah Nasional No. 43/DSN-MUI/VIII/2004 tentang Ganti Rugi (Ta'widh), firman Allah dalam QS. Al Baqarah (2): 194:

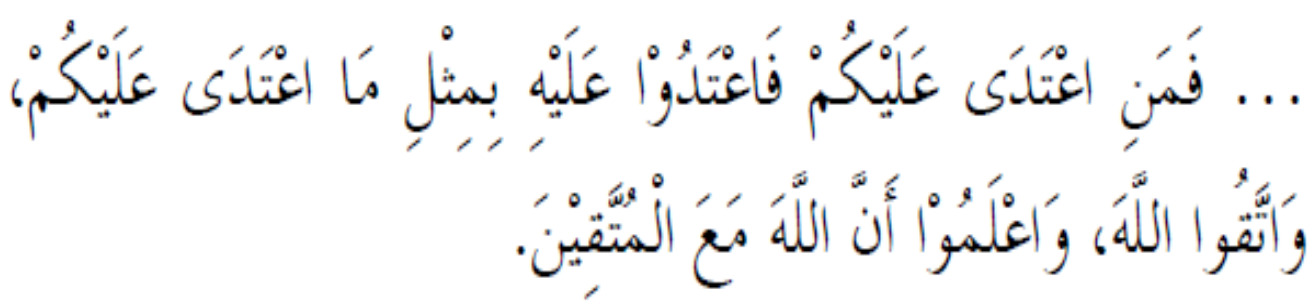

Artinya: “...maka, barang siapa melakukan aniaya (kerugian) kepadamu, balaslah ia, seimbang dengan kerugian yang telah ia timpakan kepadamu. Bertakwalah kepada Allah dan ketahuilah, bahwa Allah beserta orang-orang yang bertakwa."

Sebagaimana dasar dalam ajaran agama islam yang telah diuraikan diatas, beserta kejadian lain yang terus terjadi, kehadiran negara melalui lembaga Ombudsman yang diberi kewenangan untuk menilai kerugian masyarakat yang ditimbulkan oleh penyelenggara negara dengan mekanisme Ajudikasi Khusus (AK) sebagaimana diatur dalam Pasal 50 Ayat (5) Undang-Undang RI Nomor 25 Tahun 2009 Tentang Pelayanan Publik sangat dibutuhkan. Bahwa dengan Ajudikasi Khusus masyarakat memiliki kesempatan menuntut ganti rugi melalui Ombudsman bila merasa tidak memperoleh pelayanan atau mengalami kerugian yang ditimbulkan dari penyelenggara dengan Ombudsman sebagai ajudikator. Namun, faktanya hingga saat ini mekanisme Ajudikasi Khusus belum pernah dilaksanakan.

\section{PEMBAHASAN}

\section{A. Penerapan Ajudikasi Khusus oleh Ombudsman Republik Indonesia Terhadap Penyelenggara Negara yang Maladministrasi}

Ombudsman sebagai lembaga negara yang diberi kewenangan atributif oleh undang-undang untuk mengawasi penyelenggaraan pelayanan publik sebagaimana diatur dalam Undang-Undang RI Nomor 37 Tahun 2008 Tentang 
Ombudsman dan sebagai pengawas eksternal dalam pengawasan penyelenggaraan pelayanan publik sebagaimana amanat Undang-Undang RI Nomor 25 Tahun 2009 Tentang Pelayanan Publik tentunya berkewajiban untuk melaksanakan perintah undang-undang dengan maksimal. Atas hal tersebut, penulis akan mencoba mengurai kewenangan-kewenangan yang telah diberikan oleh undang-undang, lebih khususnya kewenangan Ajudikasi Khusus yang menjadi objek penulisan tesis saat ini.

Undang-undang tentang Pelayanan Publik yang dibentuk dengan tujuan meningkatkan kualitas pelayanan publik agar menjadi baik, yakni dengan cara melakukan pengawasan aparat pelayanan publik. Pengawasan penyelenggaraan pelayanan publik dapat dilakukan dengan dua cara, yaitu pertama, pengawasan intern yang dilakukan oleh atasan dan aparat pengawasan fungsional dan kedua, pengawas eksternal yang dilakukan masyarakat secara langsung dan pengawasan yang dilakukan oleh Ombudsman untuk memberikan perlindungan hak-hak masyarakat, keadilan, dan kesejahteraan memperoleh pelayanan publik yang baik. Tujuan dari dilakukannya pengawasan terhadap pelayanan publik adalah untuk memastikan terpenuhinya hak masyarakat mengakses layanan publik yang tersedia. Peningkatan kualitas pelayanan publik akan sangat sulit didapat tanpa adanya pengawasan eksternal. Hal ini dikarenakan masih banyaknya aparat pelayanan publik yang masih belum memahami tugas dan kewajibannya dalam memberikan pelayanan yang baik kepada masyarakat.

Sebagaimana diatur dalam Pasal 6 dan Pasal 7 Undang-Undang RI Nomor 37 Tahun 2008 Tentang Ombudsman menyebutkan bahwa Ombudsman berfungsi "mengawasi penyelenggaraan pelayanan publik yang diselenggarakan oleh Penyelenggara Negara dan pemerintahan baik di pusat maupun di daerah termasuk yang diselenggarakan oleh Badan Usaha Milik Negara, Badan Usaha Milik Daerah, dan Badan Hukum Milik Negara serta badan swasta atau perseorangan yang diberi tugas menyelenggarakan pelayanan publik tertentu”.

Fungsi dan tugas Ombudsman tidak dapat dijalankan apabila lembaga tersebut tidak diberikan kewenangan. Oleh karena itu, undang-undang mengatur tentang kewenangan sebagaimana diuraikan pada Pasal 8 Undang-Undang RI Nomor 37 Tahun 2008 Tentang Ombudsman Republik Indonesia, antara lain:

a) meminta keterangan secara lisan/tertulis dari pelapor, terlapor, atau pihak lain yang terkait mengenai laporan yang disampaikan kepada Ombudsman;

b) memeriksa keputusan, surat menyurat, atau dokumen lain yang ada pada pelapor ataupun terlapor untuk mendapatkan kebenaran suatu laporan;

c) meminta klarifikasi/salinan dokumen fotokopi dokumen yang diperlukan dari instansi manapun untuk pemeriksaan laporan dari instansi terlapor; 
d) melakukan pemanggilan terhadap pelapor, terlapor, dan pihak lain yang tekait dengan laporan;

e) menyelesaikan laporan melalui mediasi dan konsiliasi atas permintaan para pihak;

f) membuat rekomendasi mengenai penyelesaian laporan, termasuk rekomendasi untuk membayar ganti rugi dan/atau rehabilitasi kepada pihak yang dirugikan; dan

g) demi kepentingan umum, mengumumkan hasil temuan, kesimpulan, dan rekomendasi.

Sebagaimana kewenangan, fungsi, dan tugas yang telah disebutkan di atas, Ombudsman RI diberi perluasan kewenangan yakni memutus sengketa pelayanan publik melalui mekanisme ajudikasi khusus terkait ganti kerugian masyarakat sebagaimana diatur dalam Pasal 50 Ayat 5 Undang-Undang RI Nomor 25 Tahun 2009 Tentang Pelayanan Publik bahwa "dalam hal penyelesaian ganti rugi, ombudsman dapat melakukan mediasi, konsiliasi, dan ajudikasi khusus".

Bahwa dari 3 (tiga) alternatif penyelesaian sebagaimana penjelasan di atas oleh penulis menerangkan bahwa mekanisme penyelesaian laporan pengaduan oleh Ombudsman untuk tahapan konsiliasi dapat dilaksanakan pada tiap tahapan pemeriksaan laporan sementara untuk penyelesaian laporan masyarakat yang melalui mediasi dilakukan setelah tahapan pemeriksaan menemukan tindakan/perbuatan maladministrasi yang dilakukan oleh penyelenggara layanan dan/atau pelaksana pelayanan publik dan penyelesaian laporan melalui mekanisme ajudikasi khusus dilakukan bilamana proses penyelesaian melalui konsiliasi dan mediasi para pihak tidak menemui kesepakatan sebagaimana diatur dalam Peraturan Ombudsman RI Nomor 26 Tahun 2017 Tentang Tata Cara Penerimaan, Pemeriksaan, dan Penyelesaian Laporan Masyarakat.

Adapun tahapan pemeriksaan laporan masyarakat di Ombudsman oleh penulis menggambarkan dalam skema dibawah ini:

\begin{tabular}{|c|c|c|}
\hline $\begin{array}{l}\text { Penerimaan dan } \\
\text { Verivikasi Laporan }\end{array}$ & Pemeriksaan & $\begin{array}{l}\text { Resolusi dan } \\
\text { Monitoring }\end{array}$ \\
\hline 1. Registrasi & 1. Konsiliasi & 1. Mediasi \\
\hline 2. Pelimpahan & 2. LAHP d/a BAPL & $\begin{array}{l}\text { 2. Ajudikasi Khusus } \\
\text { 3. Rekomendasi }\end{array}$ \\
\hline
\end{tabular}




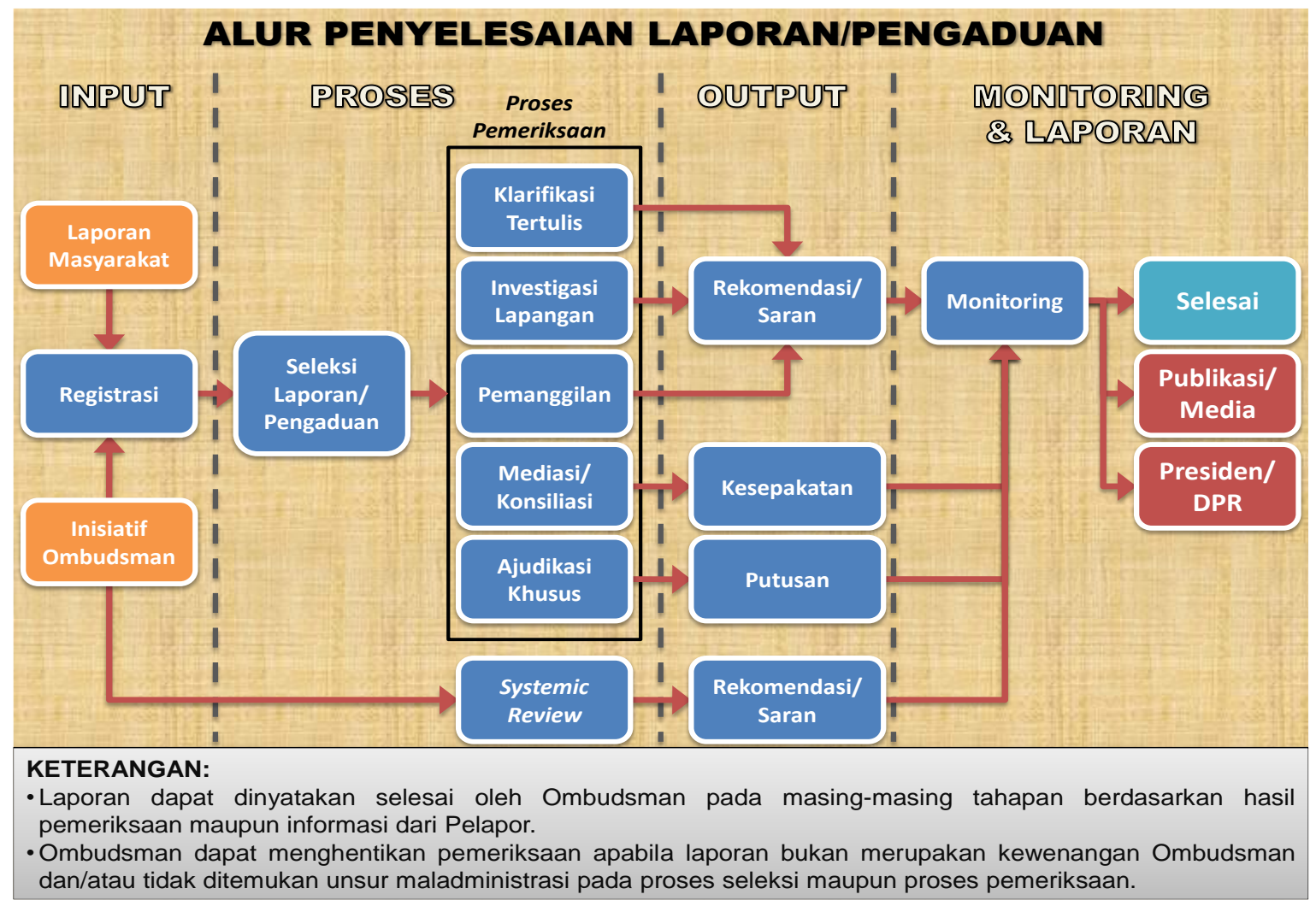

Ket. Tahapan penanganan laporan pengaduan masyarakat.

\section{Mekanisme Penyelesaian Sengketa Layanan Publik Melalui Ajudikasi Khusus}

Sebagaimana yang telah disebutkan sebelumnya undang-undang tentang Ombudsman menyatakan Ombudsman berwenang menyelesaikan laporan melalui mediasi dan konsiliasi atas permintaan para pihak. Di sisi lain, pasal 50 ayat (5) Undang-Undang tentang Pelayanan Publik memberi perluasan kewenangan dengan menyatakan dalam hal penyelesaian ganti rugi, Ombudsman dapat melakukan mediasi, konsiliasi, dan ajudikasi khusus.

Berdasarkan Pasal 1 angka 11 Undang-undang RI Nomor 25 Tahun 2009 Tentang Pelayanan Publik memberi pengertian bahwa "Ajudikasi adalah proses penyelesaian sengketa pelayanan publik antara para pihak yang diputus oleh Ombudsman". Undang-undang tentang Pelayanan Publik juga menyatakan secara khusus mengenai jenis sanksi administrasi, termasuk sanksi pembekuan misi dan/atau ijin yang diterbitkan oleh instansi pemerintah, serta pencabutan ijin yang diterbitkan oleh instansi pemerintah. Dengan kewenangan yang cukup kuat 
diharapkan Ombudsman menjadi salah satu lembaga negara yang mempunyai fungsi strategis dalam mendorong terwujudnya pemerintahan yang baik dan bersih. Namun, sejak disahkannya undang-undang pelayanan publik pada tanggal 18 Juli 2009 hingga saat ini, ketentuan Pasal 50 Ayat (5) Undang-Undang RI Nomor 25 Tahun 2009 Tentang Pelayanan Publik terkait pemutusan sengketa layanan publik melalui mekanisme Ajudikasi Khusus hingga saat ini belum terlaksana.

Dalam undang-undang pelayanan publik, Pengertian Sengketa Pelayanan Publik secara stipulatif tidak ditemukan dalam pasal-pasal Undang-Undang tersebut. Sementara dalam Kamus bahasa Indonesia Sengketa diartikan sebagai: "(1) sesuatu yang menyebabkan perbedaan pendapat; pertengkaran; perbantahan: perkara yang kecil dapat juga menimbulkan -- besar; daerah --, daerah yang menjadi rebutan (pokok pertengkaran); (2) pertikaian; perselisihan: -- di dalam partai itu akhirnya dapat diselesaikan dengan baik; (3) perkara (dalam pengadilan): tidak ada -- yang tidak dapat diselesaikan (diakses pada tanggal 12 Maret 2020 http/kamusbahasaindonesia.org/sengketa)

Dalam Undang-Undang Pelayanan Publik, mengenai Sengketa Pelayanan Publik diatur dalam beberapa pasal yaitu Pasal 1 angka 10 dan 11:

"Mediasi adalah penyelesaian sengketa pelayanan publik antar para pihak melalui bantuan, baik oleh ombudsman sendiri maupun melalui mediator yang dibentuk oleh ombudsman"

"Ajudikasi adalah proses penyelesaian sengketa pelayanan publik antarpara pihak yang diputus oleh ombudsman”

Pasal lain dalam Undang-undang Pelayanan Publik berkenaan dengan sengketa Pelayanan Publik juga ditemukan dalam Pasal 40 dan Pasal 46. Pasal 40 berisi:

(1) Masyarakat berhak mengadukan penyelenggaraan pelayanan publik kepada Penyelenggara, Ombudsman, dan/atau Dewan Perwakilan Rakyat, Dewan Perwakilan Rakyat Daerah Provinsi, Dewan Perwakilan Rakyat Daerah Kabupaten/Kota.

Sedangkan isi Pasal 46:

(1) Ombudsman wajib menerima dan berwenang memproses pengaduan dari masyarakat mengenai penyelenggaraan pelayanan publik sesuai dengan Undang-Undang ini;

(2) Ombudsman wajib menyelesaikan pengaduan masyarakat apabila pengadu menghendaki penyelesaian pengaduan tidak dilakukan oleh Penyelenggara. 
(3) Ombudsman wajib membentuk perwakilan di daerah yang bersifat hierarkis untuk mendukung tugas dan fungsi ombudsman dalam kegiatan pelayanan publik.

(4) Pembentukan perwakilan Ombudsman di daerah sebagaimana dimaksud pada ayat (3) dilakukan paling lambat 3 (tiga) tahun sejak UndangUndang ini diundangkan.

(5) Ombudsman wajib melakukan mediasi dan konsiliasi dalam menyelesaikan pengaduan atas permintaan para pihak.

(6) Penyelesaian pengaduan sebagaimana dimaksud pada ayat (2) dapat dilakukan oleh perwakilan Ombudsman di daerah.

(7) Mekanisme dan tata cara penyelesaian pengaduan oleh ombudsman diatur lebih lanjut dalam peraturan Ombudsman."

Selain itu, dalam Peraturan Ombudsman Republik Indonesia Nomor 26 Tahun 2017 Tentang Tata Cara Penerimaan, Pemeriksaan, dan Penyelesaian Laporan diatur beberapa hal mengenai penyelesaian sengketa pelayanan publik yang diselesaikan melalui ajudikasi di Ombudsman, yaitu:

Pasal 1 angka 7:

"Laporan adalah pengaduan atau penyampaian fakta yang diselesaikan atau ditindaklanjuti oleh Ombudsman yang disampaikan secara tertulis atau lisan oleh setiap orang yang telah menjadi korban maladministrasi"”

Pasal 1 angka 8:

"Pelapor adalah warga negara Indonesia atau penduduk yang memberikan laporan ke Ombudsman"

Pasal 1 angka 10:

"Terlapor adalah penyelenggara negara, pemerintah, atau badan swasta serta perseorangan yang diduga melakukan maladministrasi yang dilaporkan kepada Ombudsman"

Pasal 38:

(1) Ajudikasi khusus dapat dilakukan untuk laporan terkait penyelesaian ganti rugi yang tidak dapat diselesaikan dengan konsiliasi dan mediasi

(2) Ajudikasi Khusus dilakukan setelah proses Pemeriksaan yang menyatakan ditemukan maladministrasi.

Bahwa untuk melaksanakan Pasal 50 ayat (7) Undang Undang Nomor 25 Tahun 2009 Tentang Pelayanan Publik dan Pasal 39 Peraturan Ombudsman Nomor 26 Tahun 2017 Tentang Tata Cara Penerimaan, Pemeriksaan, dan Penyelesaian Laporan, Ombudsman menetapkan Peraturan Ombudsman Nomor 31 Tahun 2018 Tentang Mekanisme dan Tata Cara Ajudikasi Khusus. Bahwa 
dengan terbitnya peraturan tersebut ketentuan mengenai pelaksanaan ajudikasi khusus menurut hemat penulis menjadi semakin jelas dan telah sesuai dengan perintah undang-undang sebagaimana diamanatkan dalam Pasal 50 Ayat (5) Undang-Undang RI Nomr 25 Tahun 2009 Tentang Pelayanan Publik.

Mekanisme prosedur Ajudikasi Khusus sebagaimana diatur Peraturan Ombudsman Nomor 31 Tahun 2018 Tentang Mekanisme dan Tata Cara Ajudikasi Khusus, yaitu :

Pasal 1 angka 5 :

"Ajudikasi adalah proses penyelesaian ganti rugi atas sengketa pelayanan publik yang diputus oleh Ombudsman”.

Pasal 1 angka 6:

"Ajudikasi Khusus adalah Ajudikasi yang hanya terkait dengan penyelesaian ganti rugi. Penyelesaian ganti rugi dalam ketentuan ini dimaksudkan apabila tidak dapat diselesaikan dengan Mediasi dan Konsiliasi”.

Pasal 1 angka 7:

"Ajudikator adalah pihak yang ditunjuk untuk menyelesaikan permohonan ganti rugi dalam persidangan Ajudikasi Khusus"

Adapun asas dan tujuan Ajudikasi Khusus, yaitu:

Pasal 2

"Persidangan Ajudikasi Khusus dilakukan dengan cepat, sederhana, independen, terbuka untuk umum, dan tidak dipungut biaya”.

Tujuan

Pasal 3

Persidangan Ajudikasi Khusus bertujuan:

a. Memastikan tanggung jawab Pemerintah memberikan pelayanan publik yang baik.

b. Menjamin dan memastikan pemenuhan hak masyarakat dalam mengajukan penyelesaian ganti rugi.

Sebagaimana ketentuan pasal 1 angka 6 di atas bahwa mekanisme Ajudikasi Khusus adalah mekanisme terakhir yang dapat dilakukan oleh Pelapor yang merasa dirugikan akibat tindakan Terlapor setelah proses konsiliasi dan mediasi tidak berhasil yang artinya Ajudikasi Khusus belum dapat dilaksanakan sebelum kedua mekanisme tersebut dilakukan.

Secara umum, mekanisme penyelesaian sengketa layanan publik melalui Ajudikasi Khusus mirip dengan mekanisme persidangan lembaga peradilan, terutama bila melihat adanya putusan, serupa putusan pengadilan, sebagai hasil akhir dalam penyelesaian sengketa pelayanan publik ini. Persoalannya adalah 
bagaimana kekuatan putusan ini, sebab Ombudsman bukanlah lembaga pengadilan atau forum pengadilan seperti halnya arbitrase.

Sementara di sisi pelaksanaan putusan Ajudikasi Khusus menurut Pasal 25 Peraturan Ombudsman Nomor 31 Tahun 2018 Tentang Mekanisme dan Tata Cara Ajudikasi Khusus, yaitu:

(1) Putusan Ajudikasi Khusus bersifat final, mengikat dan wajib dilaksanakan oleh Terlapor;

(2) Putusan Ajudikasi Khusus dilaksanakan oleh Terlapor dalam waktu paling lama 60 (enam puluh) hari sejak putusan diterima oleh Terlapor;

(3) Putusan Ajudikasi Khusus akan disampaikan kepada Terlapor, Atasan Terlapor, DPR, dan Presiden;

(4) Ombudsman melaksanakan monitoring untuk memastikan pelaksanaan putusan Ajudikasi Khusus.

(5) Penyelenggara pelayanan publik yang tidak melaksanakan putusan Ajudikasi Khusus sebagaimana dimaksud pada ayat (1) dikenakan sanksi sesuai dengan ketentuan peraturan perundang-undangan.

Melihat Putusan Ajudikasi Khusus yang bersifat final dan mengikat sebagaimana Pasal 1 di atas, tentunya pihak Terlapor dalam hal ini penyelenggara pelayanan publik/pelaksana pelayanan publik yang melakukan maladministrasi tidak diberi upaya hukum lain selain mentaati putusan tersebut.

Di sisi lain, dengan terbitnya peraturan Ombudsman Nomor 31 Tahun 2018 Tentang Ajudikasi Khusus, bagi masyarakat belum dapat mengajukan tuntutan ganti rugi atau kompensasi atas kerugian yang dialami dalam pelayanan publik kepada Ombudsman untuk memperoleh keputusan. Adapun alasan mengapa belum diterapkan, antara lain karena sampai saat ini sudah lebih dari 10 (sepuluh) tahun sejak terbit Undang-Undang Pelayanan Publik belum ada peraturan presiden mengenai ketentuan tentang pembayaran ganti rugi sebagaimana amanat pasal 50 ayat 6 dan 8 Undang-undang RI Nomor 25 Tahun 2009 Tentang Pelayanan Publik bahwa "Ajudikasi Khusus sebagaimana dimaksud pada Ayat (5) dilaksanakan paling lambat 5 (lima) tahun sejak undang-undang ini diundangkan" dan "mekanisme dan ketentuan pembayaran ganti rugi sebagaimana dimaksud pada ayat (3) dan ayat (5) diatur lebih lanjut dalam peraturan presiden”. Dengan demikian, ketika suatu putusan Ajudikasi Khusus diputuskan oleh Ombudsman, penyelenggara yang melakukan maladministrasi dan wajib memberikan ganti rugi belum memiliki mekanisme terkait mekanisme pembayaran ganti rugi.

Berkaitan dengan potensi persinggungan kewenangan Ombudsman dan Badan Peradilan, potensi persinggungan antara putusan Ajudikasi Khusus 
Ombudsman dan badan peradilan menurut hemat penulis adalah saling melengkapi dan tidak dalam konteks saling bertentangan. Bahkan keduanya, yakni Ajudikasi Khusus dan upaya hukum melalui badan peradilan merupakan bentuk perlindungan maksimal dari negara kepada hak masyarakat selaku korban pelayanan publik. Mengingat bahwa tugas negara adalah menyelenggarakan administrasi pemerintahan dan memberikan pelayanan publik (dikutip dari website ombudsman.go.id Artikel Ajudikasi Khusus Ombudsman VS Komitmen Pelayanan Publik, Selasa, 04/09/2018 oleh Dominikus Dalu Sogeng Asisten Madya Ombudsman RI).

Penerapan Undang-Undang Pelayanan Publik terkait kewenangan Ajudikasi Khusus oleh Ombudsman memiliki implikasi sebagai berikut: Pertama, putusannya bersifat final dan mengikat sebagaimana ketentuan pasal 52 ayat 2 Jo pasal 53 ayat 2 Undang-Undang Pelayanan Publik yang diperkuat oleh Peraturan Ombudsman. Kedua, bila putusan Ajudikasi Khusus dirasa belum memberikan rasa keadilan atau masih terdapat keberatan oleh masyarakat yang merasa dirugikan maka baik secara perdata maupun pidana, masyarakat diberikan kesempatan untuk mengajukan upaya hukum sebagaimana ketentuan pasal 52 ayat 1 Jo pasal 53 ayat 1 Undang-Undang Pelayanan Publik. Ketiga, rezim Undang- Undang ini mengatur bahwa penyelenggara pelayanan tidak diberikan ruang untuk mengajukan upaya hukum bila Ombudsman sudah menerbitkan putusan Ajudikasi Khusus dan karena sifatnya final dan mengikat sehingga harus dijalankan. Hal ini juga sebagai bentuk tanggungjawab negara kepada masyarakat selaku pengguna layanan. Keempat, kesempatan yang diberikan kepada masyarakat untuk menempuh upaya hukum setelah putusan Ajudikasi Khusus dapat dimaknai sebagai salah satu sarana masyarakat memperjuangkan haknya disamping upaya hukum sehingga tidak terdapat potensi pertentangan antara institusi Ombudsman dan kewenangan yudisial. Kelima, dalam pengalaman Ombudsman, masyarakat yang tidak puas dengan penyelenggara pelayanan dapat menggunakan rekomendasi atau saran Ombudsman tentang suatu perbuatan maladministrasi sebagai bukti bila mengajukan upaya hukum melalui badan peradilan dan dalam beberapa kasus yang terjadi, baik perdata maupun pidana, hakim selalu menjadikan bukti dari Ombudsman tersebut sebagai pertimbangan putusan. Hal ini memperkuat argumentasi bahwa Ombudsman bukan lembaga penegak hukum walaupun tugasnya mengawasi penegak hukum dalam hal pelayanan publik (dikutip dari website ombudsman.go.id Artikel Ajudikasi Khusus Ombudsman VS Komitmen Pelayanan Publik, diakses Selasa, 04/09/2018 oleh Dominikus Dalu Sogeng Asisten Madya Ombudsman RI). 
Menurut hemat penulis, pembentukan dan pemberlakuan undang-undang pelayanan publik yang diundangkan pada tahun 2009 merujuk pada ketentuan Undang-Undang RI Nomor 10 Tahun 2004 Tentang Pembentukan Peraturan Perundang-undangan, sehingga asas dan tujuan pembentukannya sesuai dengan norma yang berlaku pada undang-undang tersebut. Sebagaimana ketentuan Pasal 50 Undang-Undang RI Nomor 10 Tahun 2004 Tentang Pembentukan Peraturan Perundang-undangan bahwa "peraturan perundang-undangan mulai berlaku dan mempunyai kekuatan mengikat pada tanggal diundangkan, kecuali ditentukan lain di dalam peraturan perundang-undangan yang bersangkutan”.

Penentuan berlakunya suatu peraturan perundang-undangan yang tidak sama dengan tanggal pengundangannya, dimungkinkan untuk persiapan sarana dan prasarana serta kesiapan aparatur pelaksana peraturan perundang-undangan tersebut. Dengan demikian, jika tidak ditentukan lain, disebut atau tidak disebut mulai kapan mulai berlakunya suatu ketentuan undang-undang, maka secara otomatis undang-undang itu berlaku mengikat untuk umum sejak tanggal ia diundangkan. Memang sudah menjadi "ius comminis opinion doctorum” yang diakui umum di dunia ilmu hukum bahwa suatu norma hukum itu mulai berlaku sejak ditetapkan, kecuali jika ditentukan lain oleh norma hukum itu sendiri. ${ }^{3}$

Merujuk hal diatas, penentuan berlakunya suatu norma dalam undangundang dapat dilakukan untuk memastikan sumber daya manusia, sarana dan prasarana hukum telah siap, tentunya pembuat undang-undang telah memikirkan dengan baik terkait proses pemberlakuan norma hukum tersebut dimana ketentuan Pasal 50 Ayat (6) Undang-undang Pelayanan Publik memberi waktu selama 5 (lima) tahun kepada Ombudsman untuk menjalankan norma hukum tersebut dan pasal 60 Ayat (7) Undang-undang Pelayanan Publik yang intinya memberi waktu kepada Presiden selama 6 (enam) bulan untuk membuat Peraturan Presiden yang mengatur mengenai mekanisme dan ketentuan pemberian ganti rugi. Faktanya walaupun aturan mengenai tata cara dan proses persidangan oleh Ombudsman telah ada, namun hingga saat ini mekanisme penyelesaian sengketa melalui Ajudikasi Khusus belum pernah diterapkan karena ketentuan sebagaimana amanat pasal 60 Ayat (7) Undang-undang Pelayanan Publik belum diatur, dengan demikian norma hukum yang diatur dalam Pasal 50 Ayat (6) Undang-undang pelayanan publik menjadi tidak efektif dalam pelaksanaaannya.

\footnotetext{
3 Jimlu Asshiddiqie, Perkembangan dan Konsolidasi Lembaga Negara Pasca Reformasi, Sinar Grafika Cetakan kedua, Jakarta. 2012, h.218
} 


\section{B. Faktor-Faktor Yang Mempengaruhi Penerapan Ajudikasi Khusus oleh Ombudsman Republik Indonesia Terhadap Penyelenggara Negara yang Maladministrasi}

\section{Faktor Hukum}

Penerapan Ajudikasi khusus oleh Ombudsman sebagaimana diatur dalam Pasal 50 Ayat (5) Undang-Undang RI Nomor 25 Tahun 2009 Tentang Pelayanan Publik Jo Pasal 38 Peraturan Ombudsman Republik Indonesia Nomor 26 Tahun 2017 Tentang Tata Cara Penerimaan, Pemeriksaan, Dan Penyelesaian Laporan dan Peraturan Ombudsman Nomor 31 Tahun 2018 Tentang Mekanisme dan Tata Cara Ajudikasi Khusus menunjukkan bahwa institusi Ombudsman telah menjalankan amanat sebagaimana perintah undang-undang. Namun di sisi lain, sebagaimana yang telah dijelaskan sebelumnya, mekanisme penentuan ganti rugi dari putusan Ajudikasi Khusus yang diatur melalui Peraturan Presiden hingga saat ini belum ada. Atas hal tersebut, penulis mencoba mengurai faktor-faktor yang mempengaruhi tidak terlaksananya perintah undang-undang pelayanan publik.

Dari uraian terkait penerapan mekanisme Ajudikasi Khusus yang telah diterangkan sebelumnya, mestinya Ajudikasi Khusus telah dilakukan saat ini, sebagaimana mandat pada Pasal 50 Ayat (6) Undang-Undang RI Nomor 25 Tahun 2009 Tentang Pelayanan Publik bahwa "Ajudikasi khusus sebagaimana dimaksud pada Ayat (5) dilaksanakan paling lambat 5 (lima) tahun sejak undang-undang ini diundangkan" dan Pasal 60 Ayat (7) bahwa "Peraturan Presiden mengenai mekanisme dan ketentuan pemberian ganti rugi sebagaimana dimaksud dalam Pasal 50 ayat (8) harus ditetapkan paling lambat 6 (enam) bulan sejak undangundang ini diundangkan". Kata "dilaksanakan" dan "ditetapkan" dalam undangundang ini dikaitkan dengan tanggal pengundangan, yaitu pada 18 Juli 2009, sedangkan pelaksanaan efektif pasal 50 Ayat (6) paling lambat 5 (lima) tahun sementara Pasal 60 Ayat (7) pelaksanaan efektifnya paling lambat 6 (enam) bulan kemudian. Dengan demikian di sini dibedakan antara tanggal keberlakuan dan tanggal pelaksanaan efektif. Oleh karena itu, yang dapat dibedakan atau bahkan dipisahkan adalah antara pengesahan formal undang-undang dan pemberlakuan normanya untuk mengikat bagi segenap subjek hukum yang diaturnya dengan segala hak dan kewajiban yang timbul dari pemberlakuan itu.

Menurut Jimmly Asshiddiqie, suatu norma dianggap sah sebagai norma hukum (legal norm) yang mengikat untuk umum apabila norma hukum itu berlaku karena diberlakukan atau karena dianggap berlaku oleh para subjek hukum yang diikatnya. Keberlakuan ini dalam bahasa Inggris disebut "validity", 
dalam bahasa Jerman "geltung", atau dalam bahasa Belanda disebut "gelding". Keabsahan berlakunya suatu undang-undang atau peraturan perundang-undangan itu sendiri pada pokoknya ditentukan oleh banyak faktor dan beraneka cara pandang. Secara umum dapat dikemukakan adanya empat kemungkinan faktor yang menyebabkan norma hukum dalam undang-undang atau peraturan perundang-undangan dikatakan berlaku.

Norma-norma hukum dimaksud dapat dianggap berlaku karena pertimbangan yang bersifat filosofis, yuridis, sosiologis, politis, ataupun dianggap berlaku karena pertimbangan yang semata-mata bersifat administratif. Untuk undang-undang dikatakan baik, sudah seharusnya kelima syarat di atas dipenuhi sekaligus, yaitu berlaku baik secara filosofis, yuridis, sosiologis, politis, maupun secara administratif.

\section{a. Keberlakuan Filosofis}

Suatu norma hukum dikatakan berlaku secara filosofis apabila norma hukum itu memang bersesuaian dengan nilai-nilai filosofis yang dianut oleh suatu negara. Seperti dalam pandangan Hans Kelsen mengenai "gerund-norm" atau dalam pandangan Hans Nawiasky tentang "staatsfundamentalnorm", pada setiap negara selalu ditentukan adanya nilai-nilai dasar atau nilai-nilai filosofis tertinggi yang diyakini sebagai sumber dari segala sumber nilai luhur dalam kehidupan kenegaraan yang bersangkutan (Jimly Asshiddiqie dan Muchammad Ali Safa'at, 2006).

Untuk hal ini, nilai-nilai filosofis negara Republik Indonesia terkandung dalam Pancasila sebagai "staatsfundamentalnorm". Di dalam rumusan kelima sila Pancasila terkandung nilai-nilai religiusitas Ketuhanan Yang Maha Esa, humanitas kemanusiaan yang adil dan beradab, nasionalitas kebangsaan dalam ikatan kebhineka-tunggal-ikaan, soverenitas kerakyatan, dan sosialitas keadilan bagi segenap rakyat Indonesia. Tidak satu pun dari kelima nilai-nilai filosofis tersebut yang boleh diabaikan atau malah ditentang oleh norma hukum yang terdapat dalam berbagai kemungkinan bentuk peraturan perundang-undangan dalam wadah Negara Kesatuan Republik Indonesia.

\section{b. Keberlakuan Yuridis}

Keberlakuan yuridis adalah keberlakuan suatu norma hukum dengan daya ikatnya untuk umum sebagai suatu dogma yang dilihat dari pertimbangan yang bersifat teknis yuridis. Secara yuridis, suatu norma hukum itu dikatakan berlaku apabila norma hukum itu sendiri memang (i) ditetapkan sebagai norma hukum berdasarkan norma hukum yang lebih superior atau yang lebih tinggi seperti dalam pandangan Hans Kelsen dengan teorinya "Stufenbau Theorie des Recht", (Hans Kelsen, Stuffenbau Theorie:1961), (ii) ditetapkan mengikat atau berlaku 
karena menunjukkan hubungan keharusan antara suatu kondisi dengan akibatnya seperti dalam pandangan J. H. A. Logemann," (Purnadi Purbacaraka dan Soerjono Soekanto, 1982:115-116), (iii) ditetapkan sebagai norma hukum menurut prosedur pembentukan hukum yang berlaku seperti dalam pandangan W. Zevenbergen (W. Zevenbergen, 1925:114-115), dan (iv) ditetapkan sebagai norma hukum oleh lembaga yang memang berwenang untuk itu. Jika keempat kriteria tersebut telah terpenuhi sebagaimana mestinya, maka norma hukum yang bersangkutan dapat dikatakan memang berlaku secara yuridis.

\section{c. Keberlakuan Politis}

Suatu norma hukum dikatakan berlaku secara politis apabila pemberlakuannya itu memang didukung oleh faktor-faktor kekuatan politik yang nyata (riele machtfactoren). Meskipun norma yang bersangkutan didukung masyarakat lapisan akar rumput, sejalan pula dengan cita-cita filosofis negara, dan memiliki landasan yuridis yang sangat kuat, tetapi tanpa dukungan kekuatan politik yang mencukupi di parlemen, norma hukum yang bersangkutan tidak mungkin mendapatkan dukungan politik untuk diberlakukan sebagai hukum. Dengan perkataan lain, keberlakuan politik berkaitan dengan teori kekuasaan (power theory) yang pada gilirannya memberikan legitimasi pada keberlakuan suatu norma hukum semata-mata dari sudut pandang kekuasaan. Apabila suatu norma hukum telah mendapatkan dukungan kekuasaan, apapun wujudnya dan bagaimanapun proses pengambilan keputusan politik tersebut dicapainya sudah untuk menjadi dasar legitimasi bagi keberlakuan norma hukum bersangkutan dari segi politik.

\section{d. Keberlakuan Sosiologis}

Pandangan sosiologis mengenai keberlakuan ini cenderung mengutamakan pendekatan yang empiris dengan mengutamakan beberapa pilihan kriteria, yaitu (i) kriteria pengakuan (recognition theory), (ii) kriteria penerimaan (reception theory), atau (iii) kriteria faktisitas hukum. Kriteria pertama (principle of recognition) menyangkut sejauh mana subjek hukum yang diatur memang mengakui keberadaan dan daya ikat serta kewajibannya untuk menundukkan diri terhadap norma hukum yang bersangkutan. Jika subjek hukum yang bersangkutan tidak merasa terikat, maka secara sosiologis norma hukum yang bersangkutan tidak dapat dikatakan berlaku baginya.

Kriteria penerimaan sebagai kriteria kedua (principle of reception) pada pokoknya berkenaan dengan kesadaran masyarakat yang bersangkutan untuk menerima daya-atur, daya-ikat, dan daya-paksa norma hukum tersebut baginya. Inilah yang dijadikan dasar oleh Christian Snouck Hurgronje untuk menyatakan bahwa di Hindia Belanda dahulu yang berlaku adalah hukum adat, bukan hukum 
Islam. Menurutnya, kalaupun hukum Islam itu secara sosiologis dapat dikatakan berlaku, maka hal itu semata-mata disebabkan oleh kenyataan bahwa masyarakat hukum adat sudah meresepsikannya ke dalam tradisi hukum adat masyarakat setempat.

"Pendapat Christian Snouck Hurgronje ini banyak ditentang oleh para sarjana Indonesia, terutama oleh Prof. Dr. Mr. Hazairin beserta muridmuridnya, seperti Thalib, Mohammad Daud Ali, dan sebagainya. Bahkan, sarjana Belanda sendiri sarjana hukum van den Berg mempunyai pendapat yang sama sekali berbeda dengan Snouck H. mengenai soal ini yang dikenal dengan istilah teori "receptio in complexu". Sedangkan, seperti Sayuti dan Sayuti Thalib mengembangkan teori yang dikenal dengan "receptie a contrario" (Hazairin, 1963:168).

Sedangkan kriteria ketiga menekankan pada kenyataan faktual (faktisitas hukum), yaitu sejauhmana norma hukum itu sendiri memang sungguh-sungguh berlaku efektif dalam kehidupan nyata masyarakat. Meskipun suatu norma hukum secara yuridis formal memang berlaku, diakui (recognized), dan diterima (received) oleh masyarakat sebagai sesuatu yang memang ada (exist) dan berlaku (valid), tetapi dalam kenyataan praktiknya sama sekali tidak efektif, berarti dalam faktanya norma hukum itu tidak berlaku. Oleh karena itu, suatu norma hukum baru dapat dikatakan berlaku secara sosiologis apabila norma hukum dimaksud memang berlaku menurut salah satu kriteria tersebut.

Dari penjelasan di atas, pemberlakuan pasal 50 Ayat (5) Undang-Undang Pelayanan Publik belum terlaksana karena belum adanya Peraturan Presiden yang menjadi dasar penentuan pembayaran ganti kerugian bagi masyarakat. Menurut A. W. Bradley dan K. D. Ewing, Peraturan Presiden sebagai "subordinate legislation" adalah peraturan yang ditetapkan dalam rangka melaksanakan ketentuan undang-undang sebagai "primary legislation" atau produk legislatif (legislative act) yang dibentuk oleh Dewan Perwakilan Rakyat atas persetujuan bersama dengan Presiden dan disahkan sebagaimana mestinya oleh Presiden. Peraturan induknya disebut "primary legislation", sedangkan peraturan pelaksananya disebut "subordinate legislation". Selain disebut "primary legislation", kadang-kadang peraturan induk itu disebut juga "statute", "the parent Act", atau "legislative". Sedangkan peraturan pelaksana undang undang disebut juga dengan "secondary legislation”, “delegated legislation”, "statutory instrument", dan sebagainya.

Peraturan perundang-undangan pelaksana undang-undang atau yang biasa disebut "subordinate legislations" dewasa ini dianggap memegang peranan yang sangat penting dan bahkan cenderung terus berkembang dalam praktik di hampir 
semua negara hukum modern. Sebabnya ialah bahwa parlemen atau lembaga perwakilan rakyat sebagai lembaga legislatif utama tidak mempunyai cukup banyak waktu untuk secara mendetail memberikan perhatian mengenai segala urusan teknis mengenai materi suatu undang-undang. Perumus undang-undang pada umumnya hanya memusatkan perhatian pada kerangka kebijakan dan garis besar kebijakan yang penting-penting sebagai parameter yang esensial dalam menjalankan roda dan fungsi-fungsi pemerintahan sesuai dengan tujuan yang hendak dicapai dengan ditetapkannya undang-undang yang bersangkutan.

Sedangkan, hal-hal yang bersifat teknis-operasional dari suatu kebijakan yang dituangkan dalam undang-undang biasanya dibiarkan diatur lebih lanjut oleh pemerintah atau lembaga pelaksana undang-undang lainnya dalam bentuk peraturan perundang-undangan yang lebih rendah. Peraturan perundang-undangan yang lebih rendah sebagai peraturan pelaksana itulah yang biasa disebut "subordinate legislations". Namun, seperti dikemukakan di atas, karena kewenangan legislatif itu pada pokoknya ada di tangan rakyat yang berdaulat, maka kewenangan untuk membentuk "subordinate legislations" itu juga harus dipahami berasal dari rakyat. Karena itu, lembaga pemerintah dan lembaga pelaksana undang-undang lainnya, tidak dapat menetapkan suatu peraturan perundang-undangan apapun kecuali yang diberikan atas dasar perintah atau delegasi kewenangan mengatur yang diberikan oleh lembaga perwakilan rakyat melalui undang-undang. Artinya keabsahan proses pembentukan peraturan perundang-undangan di bawah undang-undang haruslah didasarkan atas "legislative delegation of rule-making power" dari pembentuk undang-undang kepada pembentuk peraturan yang dimaksud.

Bentuk-bentuk peraturan pelaksanaan undang-undang ini di berbagai negara berbeda-beda, tergantung kebutuhan sesuai dinamika perkembangan masing-masing negara. Di Inggris, dikenal adanya (i) rules, (ii) orders, (iii) regulations, dan (iv) warrants yang dulunya disebut "statutory rules" dan sejak 1946 disebut sebagai "statutory instruments". Di India, peraturan pelaksanaan undang-undang itu, terdiri atas: (i) rules, (ii) regulations, (iii) orders and notifications, dan (iv) Bye-laws.

Fenomena "delegated legislation" sebagai peraturan pelaksana undangundang, diakui sangat penting di semua negara. Karena pentingnya, menurut A. W. Bradley dan K. D. Ewing, maka berbagai peraturan pelaksana undang-undang itu harus memenuhi empat syarat penting, yaitu:

1. Consultation of Interests;

2. Control by Parliament;

3. Publication of Statutory Instruments; 


\section{Challenge in the Courts.}

Pembentukan "statutory instrument" tidak melibatkan peran wakil rakyat di parlemen. Pemberlakuannya juga tidak dipersyaratkan harus terlebih dulu melampaui tenggat waktu tertentu agar semua orang dapat benar-benar mengetahuinya. Juga persyaratan tidak harus diumumkan lebih dulu sebelum diberlakukan. Oleh karena itu, sebagai gantinya lembaga yang bertanggung jawab membentuknya, haruslah menerapkan prinsip transparansi, dan menurut Bradley dan Ewing, harus pula dilakukan konsultasi dengan pihak yang terkait dengan materi peraturan yang akan ditetapkan itu (the department proposing to make a new statutory instrument frequently takes steps to consult interests affected by the proposal Some Acts make this obligatory yang artinya departemen yang mengusulkan untuk membuat instrument hukum baru seringkali mengambil langkah untuk berkonsultasi dengan minat yang terkena dampak dari proposal Some Acts yang menghasilkan kewajiban ini).

Semua bentuk peraturan pelaksana undang-undang tersebut harus pula tunduk kepada pengawasan oleh lembaga perwakilan rakyat. Parlemen tidak boleh membiarkan timbulnya peraturan pelaksana undang-undang tanpa pembentuk undang-undang sendiri, mengetahui apa yang diatur dalam berbagai peraturan pelaksana itu, dan apakah hal itu sudah sesuai atau tidak dengan kewenangan pengaturan yang didelegasikan oleh pembentuk undang-undang (delegation of rule making power by the legislator). Selain itu, oleh karena pembentukan peraturan pelaksana undang-undang (subordinate legislation) itu tidak melibatkan masyarakat secara resmi sehingga kurang diketahui umum, maka peraturanperaturan demikian harus pula dipublikasikan secara resmi dan terbuka. Lebih jauh, prosedur yang bersifat baku harus pula diterapkan, yaitu untuk penomoran (numbering), pencetakan (printing), penerbitan (publishing), dan pengutipan (citing).

Sementara itu, yang keempat adalah bahwa semua bentuk peraturan pelaksana itu dapat digugat ke pengadilan melalui prosedur perkara pengujian (Judicial abstract review). Menurut A. W. Bradley dan K. D. Ewing, "If a department attempts to enforce a statutory instrument against an individual, the individual may as a defence question the validity of the instrument. The court have power to decide this question even thouh the instrument has been approved by resolution of each House of Parliement" yang artinya jika sebuah departemen berupaya untuk menegakkan instrumen hukum terhadap seseorang, individu tersebut dapat mempertanyakan validitas instrumen tersebut sebagai pembelaan. Pengadilan dapat memutuskan pertanyaan ini meskipun instrumen tersebut telah disetujui oleh resolusi dari masing-masing fraksi di DPR). Berlakunya peraturan- 
peraturan itu dapat diuji, baik mengenai materinya ataupun mengenai prosedur pembentukannya. Di Indonesia, yang pertama biasa dikenal dengan sebutan pengujian materiil, sedangkan yang kedua dikenal sebagai pengujian formal (Jimmly Asshidiqqie, 2020:273).

Dari penjelasan di atas, penulis mencoba mengemukakan pendapat bahwa penerapan Ajudikasi Khusus sebagaimana amanat undang-undang pelayanan publik yang hingga 10 (sepuluh) tahun belum terlaksana, meskipun dari segi norma hukum hal tersebut telah demikian jelas diatur dalam undang-undang, namun penerapan secara faktual belum terlaksana mengakibatkan pasal tersebut secara yuridis tidak efektif. Tentunya hal ini dapat menjadi bahan evaluasi bagi setiap pembuat undang-undang dan pelaksana undang-undang dalam proses pembentukan dan pemberian kewenangan pada suatu lembaga atau badan pemerintah untuk dapat melihat secara objektif pemberlakuan serta melakukan pengawasan secara berkala dalam pemberian kewenangan tersebut sehingga pembuat undang-undang dapat memberi saran atau dorongan serta evaluasi terkait kendala yang dihadapi bagi pihak-pihak yang telah diberi mandat untuk melaksanakan ketentuan yang telah diperintahkan.

Kepada pembuat undang-undang penulis mencoba mengemukakan pendapat agar pada setiap rancangan aturan perundang-undangan yang akan dibentuk perlu dipertimbangkan aspek filosofis, aspek yuridis, aspek sosiologis, aspek politis, dan aspek yang sifatnya administratif sehingga pemberlakuan norma hukum dapat dilaksanakan di masyarakat. Sebagaimana penjelasan asas dalam pembentukan undang-undang, yakni "setiap Pembentukan Peraturan Perundangundangan harus memperhitungkan efektivitas Peraturan Perundang-undangan tersebut di dalam masyarakat, baik secara filosofis, sosiologis, maupun yuridis". Hal tersebut, sebagaimana diatur dalam Pasal 5 huruf d Undang-Undang RI Nomor 12 Tahun 2011 Tentang Pembentukan Peraturan Perundang-Undangan bahwa "Dalam membentuk Peraturan Perundang-undangan harus dilakukan berdasarkan pada asas Pembentukan Peraturan Perundang-undangan yang baik, yang meliputi:

a. kejelasan tujuan;

b. kelembagaan atau pejabat pembentuk yang tepat;

c. kesesuaian antara jenis, hierarki, dan materi muatan;

d. dapat dilaksanakan;

e. kedayagunaan dan kehasilgunaan;

f. kejelasan rumusan; dan

g. keterbukaan. 


\section{Faktor Pembebanan Ganti Kerugian}

Menurut (Dominikus Dalu Sogeng: Asisten Madya Ombudsman RI dalam tulisannya di website ombudsman.go.id dengan Judul Artikel Ajudikasi Khusus Ombudsman VS Komitmen Pelayanan Publik, diakses Selasa, 04/09/2018) ketika rancangan Undang-Undang Pelayanan Publik sedang dalam pembahasan sekitar tahun 2007 oleh wakil pemerintah yakni Kementerian Pemberdayaan Aparatur Negara (PAN), pada saat itu. Prof. Sunaryati Hartono, wakil ketua Ombudsman RI (2000-2011), sudah sejak awal menyampaikan keberatan tentang kewenangan Ajudikasi Khusus, menurut beliau dengan tugas dan kewenangan yang diberikan oleh Undang-Undang, Ombudsman RI sudah cukup berat melihat kondisi pelayanan publik di negara ini agar tidak ditambah kewenangan Ajudikasi Khusus. Hal ini juga berkaca pada negara lain yang tradisi Ombudsmannya sudah relatif lebih lama bahkan pada Ombudsman klasik di negara asalnya Swedia, tidak ada satupun Ombudsman di dunia memiliki kewenangan melakukan kewenangan Ajudikasi Khusus. Demikian pula beberapa pakar hukum administrasi negara berpendapat serupa bahwa tidak perlu menambah kewenangan Ajudikasi Khusus. Pendapat ini lebih pada kewenangan Ajudikasi Khusus adalah mekanisme yang tidak lazim oleh Ombudsman yang adalah lembaga pemberi pengaruh (magistrature of influence) dan bukan mahkamah pemberi sanksi (magistrature of sanction). Selain karena dalam prakteknya akan tidak mudah, seperti soal anggaran, hal lain adalah menentukan besaran ganti rugi imaterial akan mengalami kesulitan. Walaupun untuk kerugian materiil relatif bisa dilakukan dengan mekanisme dan sumber daya yang ada saat ini. Akan tetapi mengingat kewenangan Ajudikasi Khusus sudah merupakan kewenangan yang dimandatkan oleh Undang-Undang Pelayanan Publik dan sampai sekarang masih berlaku maka menjadi kewajiban semua pihak untuk menjalankan mandat tersebut.

Lanjutnya, salah satu kesulitan selama ini mengenai penganggaran ganti rugi kiranya dapat diterobos dengan cara ganti rugi tersebut dibebankan kepada pejabat publik yang melakukan pelanggaran sehingga bukan diambil dari anggaran negara. Hal ini merupakan bagian dari liability atau pertanggungjawaban pribadi dari pejabat bersangkutan agar memenuhi kewajiban hukumnya sebagai pejabat publik secara sungguh-sungguh. Tinggal dirumuskan dalam rancangan Peraturan Presiden tentang hal tersebut termasuk derajat tanggung jawab pejabat publik, misalnya ditarik sampai pada dua level di atasnya. Sebagai contoh dalam kasus Operasi Tangkap Tangan (OTT) Komisi Pemberantasan Korupsi (KPK) terhadap Kalapas Sukamiskin, selain Kalapasnya yang jelas dicopot dan diproses secara hukum maka Kadiv. Pemasyarakatan dan Kakanwil Hukum dan HAM Provinsi Jawa Barat ikut bertanggung jawab secara 
administrasi dengan dibebastugaskan. Walaupun perlu dipikirkan jumlah ganti ruginya agar tidak terlalu besar, misalnya maksimal 50 juta rupiah seperti yang berlaku di beberapa tribunal pelayanan publik di Australia, karena sifatnya selain sanksi administrasi membayar ganti rugi, juga sanksi moral sebagai rekam jejak pejabat/petugas bersangkutan. Bila masyarakat belum puas maka dimungkinkan untuk upaya hukum sebagaimana mandat Undang-Undang Pelayanan Publik. Hal ini juga sebagai wujud komitmen pelayanan publik menuju birokrasi yang bersih, melayani, dan bebas dari korupsi yang adalah merupakan tujuan dari reformasi birokrasi dan revolusi mental.

Berdasarkan dengan uraian diatas, menurut hemat penulis terkait dengan faktor pembebanan ganti kerugian merujuk pada Pasal 50 Ayat (4) Undangundang Pelayanan Publik bahwa "penyelenggara wajib menyediakan anggaran guna membayar ganti rugi", dari penjelasan aturan tersebut tidak diatur secara rinci apakah beban ganti kerugian diambil dari pos anggaran penyelenggara negara yang bersumber dari Anggaran Pemerintah Belanja Negara (APBN) atau Anggaran Pemerintah Belanja Daerah (APBD) atau dari kas pribadi/individu dalam penyelenggara negara yang melakukan maladministrasi. Dalam hal ini, penulis sependapat dengan biaya ganti kerugian dibebankan kepada oknum atau pelaksana pelayanan publik yang melakukan maladministrasi dengan pertimbangan bahwa pelaksana pelayanan publik memiliki kewajiban untuk menyelenggarakan pelayanan publik yang baik kepada masyarakat. Harapannya dengan pembebanan ganti kerugian kepada pelaksana pelayanan publik, pelaksana pelayanan publik merasa memiliki tanggungjawab dan kesadaran hukum untuk menyelenggarakan pelayanan sebagaimana tugas dan fungsi yang diamanahkan kepadanya, hal tersebut sebagaimana diatur dalam Pasal 16 Undang-undang RI No. 25 Tahun 2009 Tentang Pelayanan Publik bahwa "pelaksana berkewajiban : a) melakukan kegiatan pelayanan sesuai dengan penugasan yang diberikan oleh penyelenggara, b) memberikan pertanggungjawaban atas pelaksanaan pelayanan pelayanan sesuai dengan peraturan perundang-undangan, c) memenuhi panggilan untuk hadir atau melaksanakan perintah suatu tindakan hukum atas permintaan pejabat yang berwenang dari lembaga negara atau instansi pemerintah yang berhak, berwenang dan sah sesuai dengan peraturan perundang-undangan, d) memberikan pertanggungjawaban apabila mengundurkan diri atau melepaskan tanggungjawab sesuai dengan peraturan perundang-undangan; dan e) melakukan evaluasi dan membuat laporan keuangan dan kinerja kepada penyelenggara secara berkala".

\section{Faktor Sumber Daya Manusia dan Sarana Prasarana}


Berdasarkan laporan tahunan Ombudsman Republik Indonesia Tahun

2019. Sumber Daya Manusia berperan penting dalam mendukung peningkatan kinerja Ombudsman RI. Di tahun 2019, Ombudsman RI memiliki 835 pegawai yang disebut sebagai Insan Ombudsman. Seluruh pegawai diklasifikasikan kedalam 5 jenis jabatan yaitu 9 Anggota, 243 PNS, 386 Asisten, 31 Kepala Perwakilan, dan 166 Tenaga Pendukung yang tersebar di Pusat dan 34 Perwakilan. Selain sumber daya manusia, faktor lain yang tak kalah penting dalam penyelenggaraan kewenangan yaitu kesediaan sarana dan prasarana, Mayoritas kantor di Perwakilan Ombudsman RI memiliki status sewa dengan luas dan tata ruang berbeda-beda. Kondisi tersebut sebagian besar tidak memenuhi standar gedung dan ruang. Perwakilan Maluku misalnya yang memiliki luas $208 \mathrm{~m} 2$ hanya menampung ruang seperti ruang kepala. Sementara kegiatan sehari-hari, Perwakilan melaksanakan beberapa kegiatan seperti mediasi dan pertemuan lainnya dengan stakeholder yang memerlukan ruangan yang lebih luas. Kebutuhan luas bangunan yang dibutuhkan minimal $600 \mathrm{~m} 2$ dengan rincian yang memiliki fasilitas ruang penunjang seperti ruang rapat besar, ruang rapat, ruang fasilitas pengaduan masyarakat, musala, ruang laktasi, ruang tunggu, ruang arsip, toilet, ruang lobi, ruang penyimpanan barang, dan ruang dapur. (sumber laman www.ombudsman.go.id diakses tanggal 19 Maret 2020). Sementara itu di Perwakilan Sulawesi Selatan jumlah pegawai sebanyak 20 (dua puluh) orang yang terdiri atas 1 (satu) orang Kepala Perwakilan, 12 (dua belas) orang Asisten, 4 (empat) orang Aparat Sipil Negara, 2 (dua) orang Securtiy dan 1 (satu) pramubakti. Penanganan laporan dilakukan oleh Asisten, yang terbagi dalam 3 (tiga) kelompok Keasistenan yakni Keasistenan Bidang Penerimaan dan Verifikasi Laporan, Keasistenan Bidang Penyelesaian Laporan dan Keasistenan Bidang Pencegahan. (sumber hasil wawancara dengan Insan Ombudsman Sulawesi Selatan tanggal 19 Maret 2020)

Dari data diatas, penulis menguraikan jumlah laporan masyarakat sebelum terbitnya Peraturan Ombudsman RI Nomor 31 Tahun 2018 Tentang Mekanisme dan Tata Cara Ajudikasi Khusus berdasarkan dari Laporan Tahunan Ombudsman Republik Indonesia Tahun 2017, dimana dinamika penerimaan laporan masyarakat dari tahun ke tahun memiliki trend yang terus menanjak naik, hal tersebut membuktikan bahwa lembaga Ombudsman sudah semakin dikenal oleh masyarakat. Adapun data laporan masyarakat digambarkan dalam tabel dibawah ini: 


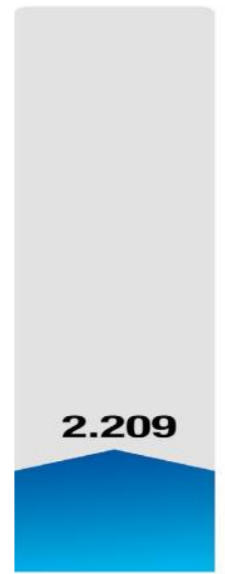

2012

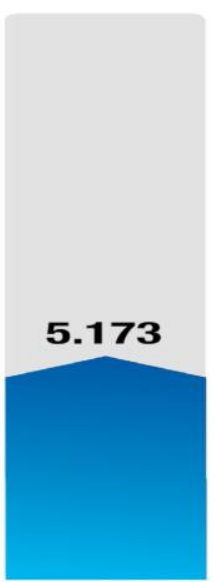

2013

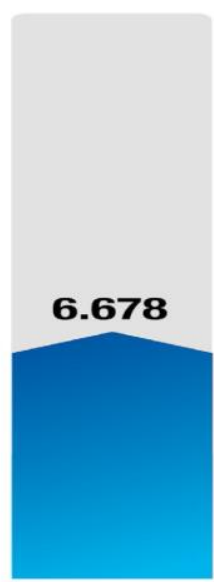

2014

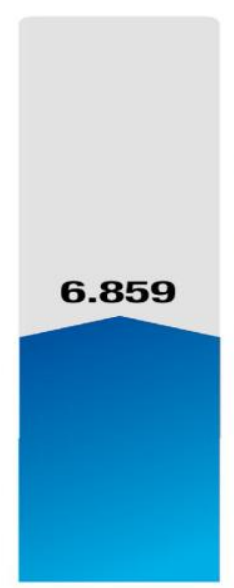

2015

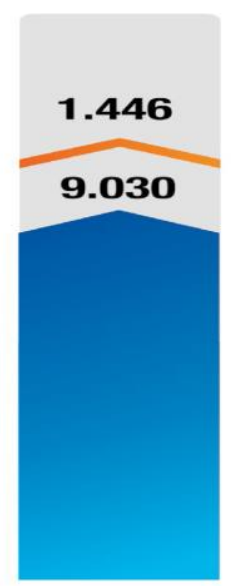

2016

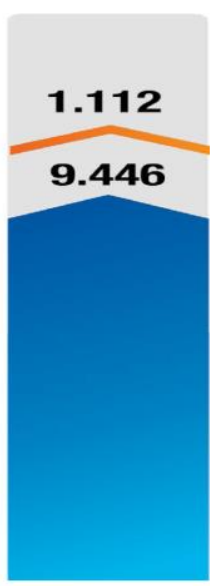

2017

Keterangan : Laporan pengaduan yang diterima Ombudsman RI sebanyak 10.558 yang merupakan laporan/ pengaduan masyarakat 9.446 dan tembusan surat pengaduan 1.112 laporan (Laporan Tahunan Ombudsman Tahun 2017 diakses dari laman website : ombudsman.go.id pada hari sabtu, 21 Maret 2020);

Dengan jumlah laporan masyarakat 9.446 seperti dalam tabel diatas dan jumlah asisten sebagai pegawai Ombudsman yang bertugas menerima dan menyelesaikan laporan masyarakat sebanyak 386 orang tentunya jumlah tersebut masih belum maksimal. Ditunjang dengan dinamika laporan yang terus menanjak membuktikan bahwa institusi Ombudsman semakin mendapat perhatian dan kepercayaan masyarakat untuk turut aktif mengawasi jalannya pemerintahan sehingga dengan keterbatasan sumber daya manusia serta sarana dan prasarana yang ada saat ini dapat terus ditingkatkan untuk pengawasan yang lebih efektif.

Sebagaimana ketentuan Pasal 27 Peraturan Ombudsman RI Nomor 31 Tahun 2018 Tentang Mekanisme dan Tata Cara Ajudikasi Khusus bahwa "perwakilan Ombudsman dapat melaksanakan Ajudikasi Khusus paling lambat 2 (dua) tahun sejak Peraturan Ombudsman ini diundangkan”. Atas ketentuan tersebut, penulis kemudian melakukan wawancara kepada insan Ombudsman dalam hal ini Kepala Perwakilan Ombudsman RI Sulawesi Selatan untuk melihat dan mendapatkan gambaran terkait kesiapan dalam pemberlakuan hal tersebut. Hasil wawancara dengan Kepala Perwakilan Ombudsman RI Perwakilan Sulawesi Selatan Bapak Subhan Djoer, ST., MH, yang dilaksanakan pada tanggal 16 Maret 2020 di Kantor Ombudsman RI Perwakilan Sulawesi Selatan, dengan keterangan :

"Bahwa sampai saat ini, dari sisi kesiapan pelaksanaan Ajudikasi Khusus di

Ombudsman RI sendiri belum ada persiapan yang berarti dan yang 
seharusnya dilakukan saat ini dalam mengantisipasi terbitnya Peraturan Presiden tersebut, Ombudsman sebaiknya melakukan persiapan dengan mengadakan pelatihan-pelatihan teknis persidangan, Standar Operasional Prosedure (SOP) pelaksanaan Ajudikasi Khusus, kesiapan sarana dan prasarana (ruang sidang) dan sumber daya manusia. Sehingga jika Peraturan Presiden terbit, maka Ombudsman RI telah memiliki persiapan dalam melaksanakannya.

Ajudikasi Khusus ini penting, karena menyangkut hajat hidup serta keadilan bagi orang banyak ditengah massifnya masalah pertanahan dalam pembangunan nasional sehingga Ajudikasi Khusus dapat menjadi penyelesaian ganti kerugian di masyarakat apalagi mekanisme Ajudikasi Khusus tanpa dipungut biaya.

Terkait kesiapan Ajudikasi Khusus, Perwakilan Sulawesi Selatan siap sepanjang diberi kewenangan untuk melaksanakan, karena Ombudsman RI adalah lembaga vertikal tentunya tunduk pada aturan yang berlaku, namun melihat kewenangan yang ada saat ini seperti Konsiliasi, Mediasi dan Rekomendasi telah cukup dalam menindaklanjuti laporan masyarakat. Adapun mengenai sarana dan prasarana yang ada saat ini secara umum dalam melakukan persidangan belum memadai".

Sebagaimana hasil wawancara diatas, penulis sependapat dengan keterangan tersebut, dimana dalam pelaksanaan Ajudikasi Khusus membutuhkan ruang sidang yang memadai, dari pertimbangan sumber daya manusia, sarana dan prasarana yang ada saat ini serta memperhatikan fungsi, tugas dan kewenangan yang diberikan oleh undang-undang tentunya dengan tambahan kewenangan Ajudikasi Khusus menurut hemat penulis, masih diperlukan tambahan sumber daya manusia untuk menunjang pelaksanaan kewenangan Ajudikasi Khusus sehingga proses penyelesaian laporan yang telah berjalan selama ini tidak terganggu. 


\section{PENUTUP}

\section{A. Kesimpulan}

Sebagai kesimpulan dari tesis ini adalah sebagai berikut :

1. Penerapan Ajudikasi Khusus oleh Ombudsman Republik Indonesia terhadap penyelenggara negara yang maladministrasi tidak efektif;

2. Faktor-faktor yang mempengaruhi tidak efektifnya penerapan Ajudikasi Khusus oleh Ombudsman terhadap penyelenggara negara yang maladministrasi adalah faktor hukum dengan tidak adanya aturan pelaksana (Peraturan Presiden) yang mengatur mekanisme dan ketentuan pembayaran ganti rugi, faktor pembebanan ganti kerugian dan faktor sumber daya manusia dan sarana prasarana.

\section{B. Saran}

Berdasarkan kesimpulan diatas, maka untuk mengatasi beberapa faktor yang menjadi penghambat dalam penerapan Ajudikasi Khusus oleh Ombudsman terhadap penyelenggara negara yang maladministrasi, maka berikut beberapa saran:

1. Agar pembuat undang-undang (legislative) sebagai pengawas melakukan evaluasi dan mendorong pihak yang tidak mentaati perintah yang telah diamanatkan undang-undang untuk melaksanakan perintah tersebut sehingga pemberlakuan undang-undang dapat efektif;

2. Agar pembuat undang-undang dalam proses pembentukan dan pemberian kewenangan pada suatu lembaga atau badan pemerintah dapat melihat secara objektif pemberlakuan serta melakukan pengawasan secara berkala dalam pemberian kewenangan tersebut;

3. Agar pembuat undang-undang pada setiap rancangan aturan perundangundangan yang akan dibentuk mempertimbangkan pemberlakuan undangundang dari aspek filosofis, aspek yuridis, aspek sosiologis, aspek politis, dan aspek yang sifatnya administratif sehingga pemberlakuan norma hukum dapat dilaksanakan. 


\section{DAFTAR PUSTAKA}

\section{Buku:}

Antonius Sujata, dkk. 2002. Ombudsman Indonesia, Masa Lalu, Sekarang dan Masa Mendatang, Komisi Ombudsman Nasional. Jakarta.

Amarah Muslimin, 1985, Beberapa Asas Dan Pengertian Pokok Tentang Administrasi Dan Hukum Administrasi, Bandung.

Antonius Sujata dan Surahman, 2002, Ombudsman Indonesia di tengah Ombudsman Internasional, Komisi Ombudsman Nasional:Jakarta.

Asshiddiqie, Jimly, 2012. Perkembangan dan Konsolidasi Lembaga Negara Pasca Reformasi, Sinar Grafika Cetakan kedua, Jakarta.

Bambang Sutiyoso, 2008, Hukum Arbitrase dan Alternatif Penyelesaian Sengketa, Gama Media. Yogyakarta.

Bachsan Mustafa, 1990, Pokok-Pokok Hukum Administrasi Negara, Citra Aditya Bakti, Bandung.

Galang Asmara, 2012. Ombudsman Republik Indonesia dalam Sistem Ketatanegaraan Republik Indonesia, Laksbang Yustitia. Surabaya.

Khotibul Umam, 2010. Penyelesaian Sengketa diluar Pengadilan, Pustaka Yustisia, Yogyakarta.

Marbun. S.F, 2013. Hukum Administrasi Negara II, FH UII Press. Yogyakarta.

Surachman. RM dan Antonius Sujata, 2002. Ombudsman Indonesia di Tengah Ombudsman Internasional, Sebuah Antologi, Jakarta.

Susanti Adi Nugroho, 2009, Mediasi Sebagai Alternatif Penyelesaian Sengketa, PT. Telaga Ilmu Indonesia, Jakarta.

\section{Jurnal:}

Asshiddiqie, Jimly. 1995. Kedudukan dan Peranan Hukum Tata Negara Dalam Pembangunan. Jurnal Hukum dan Pembangunan, Vol. 25, No. 2, link url: http://jhp.ui.ac.id, diakses pada tanggal 09 Maret 2020.

Adjiebrata, Bernardino Rakha, 2019, Tindak Lanjut Survei Ombudsman Republik Indonesia (ORI) dalam Pencegahan Maladministrasi Pelayanan Publik. Jurnal Peradilan Indonesia, Jurnal Berkala MaPPI FHUI ISSN 2460-2043 Volume 7, diakses pada tanggal 09 Maret 2020.

Setiajeng Kadarsih, 2010. Tugas dan Wewenang Ombudsman RI dalam Pelayanan Publik Menurut UU Nomor 37 Tahun 2008, Jurnal Dinamika Hukum, Fakultas Hukum Universitas Jenderal Sudirman, Purwokerto Jawa Tengah. 